\title{
STABILITAS ANTOSIANIN NASI MERAH INSTAN AKIBAT PENGARUH VARIETAS BERAS MERAH (ORYZA NIVARA. L) DAN TEKNIK PEMASAKAN MENGGUNAKAN METODE PENGERINGAN BEKU (FREEZE DRYING)
}

\author{
Sarah Maharani, Yusman Taufik, Yusep Ikrawan \\ Program Magister Teknologi Pangan, Universitas Pasundan, Jalan Sumatra No.41, Bandung, 40117, Indonesia \\ Email : sarahmaharaniyy@gmail.com
}

\begin{abstract}
Abstrak
Tujuan dari penelitian ini mengevaluasi, menganalisis serta membuktikan bahwa varietas beras merah (Oryza nivara. L) dan teknik pemasakan berpengaruh dan dengan metode pengeringan beku (Freeze drying) dapat menjaga stabilitas antosianin nasi merah (Oryza nivara. $L$ ) instan. Metode penelitian terdiri dari penelitian tahap pertama meliputi analisis bahan baku : analisis kadar antosianin, protein dan serat pangan (dietary fiber), penelitian tahap kedua menggunakan rancangan analisis Rancangan Acak Kelompok (RAK) 2 faktor meliputi varietas beras merah Inpari 24, Inpara 7, dan Inpago 7 dan teknik pemasakan Dimasak Matang dan Dimasak Setengah Matang. Terdapat 6 perlakuan, 4 kali ulangan, 24 satuan percobaan. Respon pada penelitian tahap kedua meliputi respon kimia (kadar antosianin), respon fisik (waktu rehidrasi), dan respon organoleptik (warna, aroma, rasa, dan tekstur). Olah data menggunakan metode statistik SPSS 21.0 Post Hoc Dunnet's. Penelitian tahap ketiga analisis sampel terpilih dari penelitian tahap kedua dengan dua metode pengeringan yaitu metode pengeringan beku (freeze drying) dan pengeringan panas (tunnel drying). Hasil penelitian menunjukkan adanya interaksi antara varietas beras merah dan teknik pemasakan. Hasil penelitian tahap pertama menunjukan hasil uji kadar antosianin, protein dan serat pangan (dietary fiber) dengan nilai tertinggi pada varietas Inpari 24 adalah 5,35 mg/l, 7,15\%, dan 16,34\%. Hasil penelitian tahap kedua dengan olah data statistik SPSS 21.0 Two Way Anova Post Hoc Dunnet's diperoleh hasil sampel $a_{1} b_{2}$ unggul berdasarkan respon kimia kadar antosianin $(5,13$ $\mathrm{mg} / \mathrm{l})$ dan respon organoleptik berdasarkan atribut warna $(4,72)$, rasa $(4,12)$, dan tekstur $(4,20)$. Hasil penelitian tahap ketiga analisis sampel $a_{1} b_{2}$ perbandingan dengan dua metode pengeringan yaitu metode pengeringan beku (freeze drying) dan metode pengeringan panas (tunnel drying) terhadap stabilitas nutrisi nasi merah instan secara kimia dan fisik yaitu sampel dengan metode pengeringan beku (freeze drying) memiliki nilai terbaik pada kadar antosianin $(5,13$ $\mathrm{mg} / \mathrm{l})$, protein $(4,181 \%)$, serat pangan (dietary fiber) $(12,01 \%)$ dan waktu rehidrasi (4 menit 19 detik).
\end{abstract}

\begin{abstract}
The purpose of this study is to evaluate, analyze and prove that red rice varieties (Oryza nivara. L) and cooking techniques have an effect and that the freeze drying method can maintain the stability of anthocyanin red rice (Oryza nivara. L) instant. The research method consisted of the first stage of the research which included analysis of raw materials: analysis of anthocyanin levels, protein and dietary fiber, the second stage of the study used a 2-factor Randomized Block Design (RBD) analysis design including red rice varieties Inpari 24, Inpara 7, and Inpago 7 and cooking techniques cooked and cooked half cooked. There were 6 treatments, 4 replications, 24 experimental units. The response in the second stage of the research included chemical response (anthocyanin levels), physical response (rehydration time), and organoleptic response (color, flavor, taste, and texture). Data processing uses the SPSS 21.0 Post Hoc Dunnet's statistical method. The third phase of the analysis of selected samples was from the second stage of the research with two methods of drying namely freeze drying and tunnel drying. The results showed an interaction between red rice varieties and cooking techniques. The results of the first stage of the study showed the results of anthocyanin, protein and dietary fiber levels with the highest values in the Inpari 24 variety were $5.35 \mathrm{mg} / \mathrm{l}, 7.15 \%$, and $16.34 \%$. The results of the second stage of the study with SPSS 21.0 two way Anova Post Hoc Dunnet's statistical data obtained superior alb2 samples based on chemical response levels of anthocyanin $(5.13 \mathrm{mg} / \mathrm{l})$ and organoleptic responses based on color attributes (4.72), taste $(4,12)$, and texture $(4,20)$. The results of the third phase of the analysis of the comparison of $a_{1} b_{2}$ samples with the two drying methods, namely the freeze drying method and the tunnel drying method for chemical and physical stability of instant red rice, the samples with the freeze drying method have values the best anthocyanin levels $(5.13 \mathrm{mg} / \mathrm{l})$, protein $(4.181 \%)$, dietary fiber $(12.01 \%)$ and rehydration time (4 minutes 19 seconds).
\end{abstract}

Keywords: Red Rice Varieties, Cooking Techniques, Instant Red Rice. 


\section{Pendahuluan}

Beras merah (Oryza nivara. L) merupakan salah satu jenis pangan fungsional (Fuctional Food) dengan harga jual cukup tinggi di pasaran. Tekstur nasi merah pada umumnya agak pera hingga pera sehingga kurang disukai konsumen dari segi organoleptik. Beras merah merupakan bahan pangan pokok yang memiliki nilai kesehatan tinggi. Selain mengandung karbohidrat, lemak, protein, serat, dan mineral, beras merah juga mengandung senyawa bioaktif atau senyawa ekstra nutrisi yang terdapat dalam jumlah kecil pada pangan. Senyawa bioaktif utama yang ada pada beras merah adalah senyawa fenolik. Senyawa fenolik mempunyai struktur yang khas, yaitu memiliki satu atau lebih gugus hidroksil yang terikat pada satu atau lebih cincin aromatik benzena, sehingga senyawa ini mempunyai sifat yang khas, yaitu dapat teroksidasi (Mardiah, 2017).

Persentase responden setiap wilayah di Indonesia yang pernah mengkonsumsi nasi merah bervariasi. Perbedaan ini disebabkan karena berbagai faktor diantaranya: kebiasaan, keinginan untuk mencoba mengkonsumsi beras merah, tingkat pengetahuan serta kesadaran masyarakat akan gizi beras merah dan sebagainya. Presentase responden yang menyatakan pernah mengkonsumsi nasi beras merah di provinsi Sumatera Utara $16,22 \%$, Jawa Barat $26,0 \%$, Jawa Tengah 19,0\%, Jawa Timur 23,0\%, Bali 38,0\%, Sulawesi Selatan 34,38\%, dan Nusa Tenggara Barat 31,0\% (Indrasari dan Adnyana, 2007).

Keunggulan beras merah terletak pada senyawa antosianin yang terdapat pada lapisan aleuronnya. Kadar antosianin pada beras merah berkisar rentang 0,33 $1,39 \mathrm{mg} / 100 \mathrm{~g}$. Antosianin ialah senyawa yang baik untuk kesehatan karena memiliki aktivitas antioksidan (Yodmanee dkk., 2011).

Antosianin merupakan komponen bioaktif dan warna dasar bahan makanan yang berwarna merah, ungu, biru hingga kehitaman. Warna alami pada antosianin berpotensi untuk dimanfaatkan sebagai pewarna alami untuk makanan. Konsumsi antosianin dalam diet terbukti mampu memberikan efek perlindungan terhadap penyakit kardiovaskuler, diabetes militus, antioksidan, anti inflammasi, dan antikanker, antosianin terbukti mampu menekan pertumbuhan sel HCT-15 dan HL-60 (Katsube dkk., 2003).

Beras merah mengandung komposisi gizi yang lebih banyak bila dibandingkan dengan beras putih serta komposisi energi yang dihasilkanya pun lebih besar. Beras merah mengandung thiamin (vitamin B1), zat besi yang lebih tinggi serta mengandung protein, asam lemak tidak jenuh, beta-sterol, camsterol, stigma sterol, isoflavon, saponin, $\mathrm{Zn}$, Fe, lovastin, dan mevinolinHMG-CoA. Unsur zat gizi lain yang terdapat pada beras merah salah satunya selenium yang bermanfaat mencegah penyakit kanker dan penyakit degeneratif (Galung, 2017).

Rendahnya pemanfaatan beras merah
diakibatkan karena pada proses pemasakan membutuhkan waktu yang relatif lebih lama. Hal ini karena pada beras merah masih memiliki lapisan di luar endosperma yaitu lapisan aleuron. Lapisan aleuron akan menghambat penyerapan air selama proses pemasakan. Beras merah yang juga memiliki rasa yang khas (nutty flavor) yang menyebabkan orang tidak menyukainya (Rahmat, 2010).

Nasi merah umumnya dikonsumsi secara langsung sebagai makanan pokok atau dibuat bubur ataupun kerupuk. Untuk memperpanjang umur simpan serta diversifikasi produk, salah satunya ialah dengan proses instanisasi yaitu proses olahan beras yang telah dimasak kemudian dikeringkan agar bisa disimpan dalam jangka waktu yang lebih lama, namun dapat disajikan dalam waktu yang labih cepat. Sehingga diperoleh nasi cepat masak (quick cooking rice) atau disebut juga nasi instan yaitu beras yang secara cepat dapat diubah menjadi nasi memlaui proses rehidrasi. Produk pangan instan terdapat dalam bentuk kering atau konsentrat, sifatnya yang mudah larut sehingga mudah untuk disajikan dengan hanya menambahkan air panas (Luna., dkk 2015).

Proses pengeringan nasi instan pada umumnya menggunakan metode pengeringan biasa (panas), salah satu contohnya yaitu prosedur pembuatan nasi instan mengikuti metode yang digunakan oleh (Rewthong dkk., 2011), yaitu dengan menggunakan oven dimana nasi tersebut dikeringkan pada suhu $60^{\circ} \mathrm{C}$ selama 24 jam sehingga diperoleh nasi instan yang kering, untuk mendapatkan nasi yang siap dikonsumsi maka dilakukan penanakan kembali menggunakan rice cooker dengan perbandingan $2 \mathrm{~g}$ nasi instan/3 $\mathrm{mL}$ air $(\mathrm{b} / \mathrm{v})$ hingga nasi matang.

Stabilitas antosianin relatif rendah selama proses pemanasan (pemasakan) dan penyimpanan. Senyawa antosianin lebih mudah terdegradasi karena dipengaruhi faktor pemanasan, cahaya, $\mathrm{pH}$, keberadaan oksigen, dan lain-lain. Beberapa penelitian membuktikan bahwa senyawa antosianin pada beberapa produk pangan mengalami kerusakan karena faktorfaktor tersebut, contohnya pada ekstrak antosianin dari jus wortel hitam ekstrak kasar dari bunga Ranunculus asiaticus jus acai serta minuman isotonik menggunakan beras ketan hitam. Antosianin juga telah dikembangkan menjadi pewarna alami terdapat senyawa pelindung yang stabil terhadap pemanasan, yaitu manitol (Eldridge dkk., 2014).

Dalam proses pembuatan nasi instan ini terdapat proses pengeringan beku menggunakan Freeze Drying, sebagaimana diketahui prinsip teknologi pengeringan beku (freeze drying) ini dimulai dengan proses pembekuan pangan, dan dilanjutkan dengan proses pengeringan, yaitu mengeluarkan atau memisahkan hampir sebagian besar air dalam bahan yang terjadi melalui mekanisme sublimasi. Dengan metode pengeringan beku ini diharapkan produk pangan instan tidak terjadi case-hardening diantaranya tidak terjadi proses gelatinisasi pati, karamelisasi dan 
denaturasi protein, diupayakan uap air bisa berdifusi dengan baik dari bagian basah ke udara lingkungan, sehingga dapat dihasilkan produk instan yang baik (Hariyadi, 2013).

Penelitian ini dimaksudkan untuk mengevaluasi serta menganalisa yang diduga bahwa varietas beras merah (Oryza nivara. L) dan teknik pemasakan berpengaruh dan dengan metode pengeringan beku (Freeze drying) dapat menjaga stabilitas antosianin nasi merah (Oryza nivara. L) instan.

\section{Bahan dan Metode Penelitian Bahan dan Alat}

Bahan yang digunakan dalam penelitian ini adalah beras merah dengan 3 jenis varietas yang berbeda diantaranya adalah varietas Inpari 24, Inpara 7, dan Inpago 7 yang diperoleh dari BB Padi Sukamandi Subang. Sedangkan bahan yang digunakan untuk analisis kadar protein metode kjeldahl diantaranya: garam kjeldahl, $\mathrm{H}_{2} \mathrm{SO}_{4}$, aquadest, $\mathrm{NaOH}$ $30 \%$, granula $\mathrm{Zn}, \mathrm{HCl} 0.1 \mathrm{~N}, \mathrm{NaOH} 0.1 \mathrm{~N}$, dan indikator PP. Pengujian total senyawa antosianin metode $p H$ Differensial diantaranya: buffer Kalium Klorida pH 1.0, buffer Natrium Asetat $\mathrm{pH} 4.5$ diukur absorbansinya menggunakan spektrofotometer UV-VIS pada panjang gelombang $510 \mathrm{~nm}$ dan $700 \mathrm{~nm}$. Bahan yang akan digunakan untuk analisis serat pangan (dietary fiber) metode enzimatik diantaranya: $25 \mathrm{ml}$ larutan buffer Nafosfat $0.1 \mathrm{M} \mathrm{pH} 6,0.1 \mathrm{ml}$ enzim termamyl, $\mathrm{HCl} 4 \mathrm{M}$, air destilat, 0.5 gram celite kering (berat tepat diketahui).

Alat yang digunakan dalam penelitian ini diantaranya: Freeze Dryer Tipe Eyela FD 5N, Rice Cooker, gelas kimia, labu ukur, labu erlenmeyer 250 dan $500 \mathrm{ml}$, wadah dan neraca analitik. Sedangkan alat yang digunakan untuk analisis diantaranya: neraca analitik, mortar, dan alu, tabung reaksi, kertas saring, pipet volumetri, pipet mikron, filler, batu didih, cawan petri, labu kjeldahl, labu takar, destilator, gelas ukur, erlenmeyer, buret, klem dan statif.

\section{Metode Penelitian}

Penelitian ini dilakukan melalui tiga tahap penelitian yang meliputi penelitian tahap pertama, penelitian tahap kedua dan penelitian tahap ketiga.

\section{Penelitian Tahap Pertama}

Penelitian tahap pertama meliputi analisis bahan baku yang digunakan untuk penelitian, yaitu beras merah dengan tiga varietas berbeda diantaranya Inpari 24, Inpara 7, dan Inpago 7.

Analisis kimia yang dilakukan untuk beras merah ini meliputi, kadar antosianin metode $p H$ Differential, kadar protein metode Kjeldahl, dan serat pangan (Dietary Fiber) metode Enzimatik.

\section{Penelitian Tahap Kedua}

Penelitian tahap kedua merupakan kelanjutan dari penelitian tahap pertama dengan tujuan untuk menentukan jenis varietas beras merah dan teknik pemasakan nasi yang dimasak matang dan setengah matang yang digunakan pada proses pembuatan nasi merah (Oryza nivara. L) instan dengan metode pengeringan beku (Freeze Drying). Faktor yang akan digunakan pada penelitian tahap kedua yaitu varietas beras merah (A) terdiri dari 3 taraf: a1 = Varietas Inpari 24; a $=$ Varietas Inpara 7 dan a3 = Varietas Inpago 7, serta faktor teknik pemasakan beras merah (B) terdiri dari 2 taraf, yaitu: b1 = Dimasak matang; dan b2 = Dimasak setengah matang.

Rancangan percobaan yang digunakan pada penelitian tahap kedua adalah rancangan acak kelompok (RAK) faktorial dengan 2 faktor, faktor A (varietas beras merah) terdiri dari 3 taraf dan faktor B (teknik pemasakan beras merah) terdiri dari 2 taraf, sehingga didapatkan 6 kombinasi perlakuan. Setiap perlakuan diulang sebanyak 4 kali, sehingga diperoleh 24 satuan percobaan.

Berdasarkan rancangan percobaan penelitian di atas untuk memudahkan pengujian maka dilakukan uji analisis variansi (ANAVA) Two-Way Anova dengan pengolahan data statistik menggunakan program SPSS 21.0 yang dilanjutkan Post Hoc Test Dunnet .

Rancangan respon yang dilakukan pada penelitian tahap kedua meliputi:

1) Respon Fisik

Analisis fisik yang dilakukan terhadap beras merah instan yaitu menghitung waktu rehidrasi.

2) Respon Kimia

Analisis kimia yang dilakukan terhadap beras merah instan yaitu analisis kadar antosianin dengan metode $p H$ Differential.

3) Respon Organoleptik

Respon organoleptik yang dilakukan terhadap beras merah instan yaitu uji hedonic berdasarkan kesukaan terhadap atribut warna, aroma, rasa, dan tekstur (Mouthfeel) kepada 30 orang panelis terlatih. Adapun kriteria penilaiannya sebagai berikut:

(1) Sangat Tidak Suka, (2) Tidak Suka, (3) Agak Tidak Suka, (4) Agak Suka, (5) Suka, dan (6) Sangat Suka.

\section{Deskripsi Penelitian Tahap Kedua}

Deskripsi percobaan penelitian tahap kedua proses instanisasi beras merah dengan metode pengeringan beku (freeze drying) dalam penelitian tahap kedua ini adalah sebagai berikut:

1) Pencucian

Bahan baku yang digunakan adalah beras merah varietas terpilih dari penelitian tahap kedua. Pencucian beras dilakukan dengan cara mengalirkan air kedalam wadah yang berisi beras. Pencucian ini berfungsi untuk membersihkan beras dari kotoran baik berupa pasir atau debu.

2) Pemasakan

Pemasakan bertujuan untuk mendapatkan nasi yang matang dan telah tergelatinisasi sempurna. Pemasakan pada beras instan dilakukan dengan menggunakan Rice Cooker, perbandingan air dengan 
beras adalah 1:2 dan waktu pemasakan dilakukan dilakukan selama15-20 menit.

3) Pengeringan Beku dengan Freeze Drying

Pembekuan bertujuan agar tidak terjadi pemasakan atau gelatinisasi berlebih. Jika tidak dilakukan pembekuan makan hasil nasi instan tidak transparan dan bentuknya tidak utuh dan proses mengeluarkan atau memisahkan hampir sebagian besar air dalam bahan yang terjadi melalui mekanisme sublimasi. Pembekuan pada beras dilakukan selama 24 jam pada suhu $-40^{\circ} \mathrm{C}$.

4) Analisis Respon

1. Respon Fisik

Analisis fisik yang dilakukan terhadap beras merah instan yaitu menghitung waktu rehidrasi.

\section{Respon Kimia}

Analisis kimia yang dilakukan terhadap beras merah instan yaitu analisis kadar antosianin dengan metode $p H$ Differential.

\section{Respon Organoleptik}

Respon organoleptik yang dilakukan terhadap beras merah instan yaitu uji hedonik terhadap atribut warna, aroma, rasa, dan tekstur (Mouthfeel) kepada 30 orang panelis semi terlatih.

\section{Penelitian Tahap Ketiga}

Penelitian tahap ketiga merupakan kelanjutan dari penelitian tahap kedua yaitu sampel terpilih dengan nilai tertinggi dari penelitian tahap kedua lalu dibandingkan hasil analisis kimia dan fisik sampel terpilih dari penelitian tahap kedua dengan metode pengeringan dengan menggunakan metode pengeringan beku (freeze drying) dan metode pengeringan panas (tunnel drying). Data yang digunakan pada penelitian tahap kedua adalah data yang telah dilakukan pengolahan data rancangan percobaan dengan uji lanjut Dunnet dengan nilai rata-rata data transformasi pada masing-masing respon. Sedangkan Analisa kimia yang dilakukan pada penelitian tahap ketiga adalah kadar antosianin metode $p H$ Differential, kadar protein metode Kjeldahl, dan serat pangan (Dietary Fiber) metode Enzimatik. Sedangkan analisis fisik yang dilakukan adalah menghitung waktu rehidrasi.

\section{Hasil dan Pembahasan}

\section{Penelitian Tahap Pertama}

Penelitian tahap pertama dilakukan dengan tujuan untuk mengetahui kandungan bahan baku ketiga varietas beras merah (Inpari 24, Inpara 7, dan Inpago 7). Respon analisis yang dilakukan diantaranya kadar antosianin, kadar protein dan kadar serat pangan (Dietary Fiber). Hasil analisis dapat dilihat pada Tabel 1 berikut:

Tabel 1. Hasil Analisis Bahan Baku Beras Merah (Oryza nivara. $L$ )

\begin{tabular}{|c|c|c|c|}
\hline \multirow[b]{2}{*}{$\begin{array}{c}\text { Bahan } \\
\text { Baku }\end{array}$} & \multicolumn{3}{|c|}{ Hasil Analisis } \\
\hline & $\begin{array}{c}\text { Kadar } \\
\text { Antosianin } \\
(\mathrm{mg} / \mathrm{l})\end{array}$ & $\begin{array}{c}\text { Kadar } \\
\text { Protein } \\
(\%)\end{array}$ & $\begin{array}{c}\text { Kadar Serat } \\
\text { Pangan (Dietary } \\
\text { Fiber) }(\%)(*)\end{array}$ \\
\hline Inpari 24 & 5,34 & 7,15 & 16,34 \\
\hline Inpara 7 & 4,50 & 6,93 & 10,97 \\
\hline Inpago 7 & 4,17 & 6,28 & 12,78 \\
\hline
\end{tabular}

(Sumber : PT. Saraswanti Indo Genetech, 2019) (*)

Berdasarkan hasil Tabel 1 menunjukkan bahwa pengujian kadar antosianin, kadar protein dan kadar serat pangan (dietary fiber) analisis bahan baku dengan nilai tertinggi pada varietas Inpari 24 secara berturutturut adalah 5,35 mg/l, 7,15\%, dan 16,34\%. Perbedaan hasil kandungan nutrisi ini bisa dipengaruhi oleh beberapa faktor, salah satunya adalah perbedaan varietas beras merah. Kandungan antosianin pada beras merah varietas Inpari 24 memiliki konsentrasi antosianin paling tinggi dibandingkan varietas lainnya yang berkisar antara 179 - 488 mg/100 g BK (Mardiah, 2017).

Menurut Reza (2012), bahwa kepekatan warna beras merah berbanding lurus dengan kandungan antoisianin yang ada dalam beras tersebut, semakin pekat warna merah maka semakin tinggi kandungan antosianinnya.

Sembilan puluh persen dari hasil penggilingan gabah kering salah satunya yaitu protein yang merupakan konstituen utama kemudian diikuti oleh pati dan lemak. Pada beras merah, hanya lapisan sekam yang dihilangkan sehingga pada bagian endosperm beras merah kaya akan kandungan protein dan mineral sekitar 80\% (Wang dkk., 2013).

Menurut Harini dkk., (2013) bahwa beras merah memiliki kadar serat pangan yang lebih tinggi yaitu sebesar 1,484 \% lebih tinggi dibandingkan beras putih yaitu sebesar $1,225 \%$.

Beras merah mengandung lebih banyak serat pangan di dalam aleuronnya, sedangkan beras putih yang telah mengalami proses pengelupasan hanya mengandung sedikit serat pangan (Monika dkk., 2013).

\section{Penelitian Tahap Kedua}

Penelitian tahap kedua ini merupakan kelanjutan dari penelitian tahap pertama dengan tujuan untuk mengetahui pengaruh varietas beras merah (Oryza nivara. L) dan teknik pemasakan terhadap stabilitas nutrisi beras merah instan dengan metode pengeringan beku (Freeze Drying) dengan menggunakan kontrol (pembanding) nasi merah sebelum pengeringan beku dengan metode statistik SPSS 21.0, yang kemudian dilakukan uji kimia (kadar antosianin), uji fisik (waktu rehidrasi), dan organoleptik (uji hedonik).

\section{Kadar Antosianin}

Senyawa antosianin memiliki ciri khas memberikan warna merah pada beras merah yang disebabkan oleh pigmen antosianin dalam jumlah besar yang terdapat pada lapisan padi (Afza, 2016). 


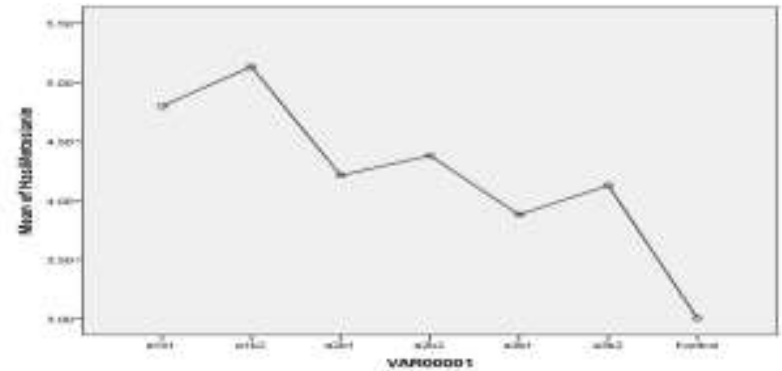

Gambar 1. Grafik Interaksi Varietas Beras Merah dan Teknik Pemasakan Terhadap Kontrol Hasil Antosianin Nasi Merah Instan

Berdasarkan data Grafik 1 diatas menunjukan bahwa secara keseluruhan perlakuan varietas beras merah dan teknik pemasakan memberikan perbedaan yang nyata $(\mathrm{p}<0,05)$ terhadap kadar antosianin nasi merah instan. Perbedaan yang nyata ini dapat disebabkan oleh salah satu faktor yang mempengaruhi warna dari antosianin adalah perubahan $\mathrm{pH}$ yang disertai dengan peningkatan suhu pada proses pemasakan antara nasi yang dimasak matang dan dimasak setengah matang karena degradasi antosianin terjadi disertai dengan adanya peningkatan suhu. Sifat asam akan menyebabkan warna antosianin menjadi merah, sedangkan sifat basa menyebabkan antosianin menjadi biru. Selain faktor perubahan $\mathrm{pH}$, konsentrasi pigmen, adanya campuran dengan senyawa-senyawa lain, jumlah gugus hidroksi juga mempengaruhi warna antosianin (Anggraeni dkk., 2018).

Menurut Syamaladevi dkk (2011), Stabilitas antosianin raspberry selama penyimpanan kering bubuk raspberry, bubuk raspberry diseimbangkan pada aktivitas air tertentu selama 37 hari dianggap sebagai titik awal studi penyimpanan. Temperatur penyimpanan $-20 \circ \mathrm{C}$ dan $-35 \circ \mathrm{C}$ dapat digunaan untuk penyimpanan jangka panjang dari raspberry beku, memberikan retensi yang lebih baik antosianin dalam waktu lama.

\section{Waktu Rehidrasi}

Menurut Juliano (1994) tingkat pengembangan dan penyerapan air tergantung pada kadar amilosa, semakin tinggi kadar amilosa maka kemampuan pati menyerap dan mengembang menjadi lebih besar karena amilosa memiliki kemampuan membentuk ikatan hidrogen yang lebih besar dibandingkan amilopektin. Sehingga beras merah pecah kulit memiliki kemampuan menyerap air yang lebih besar bila dibandingkan dengan beras giling.

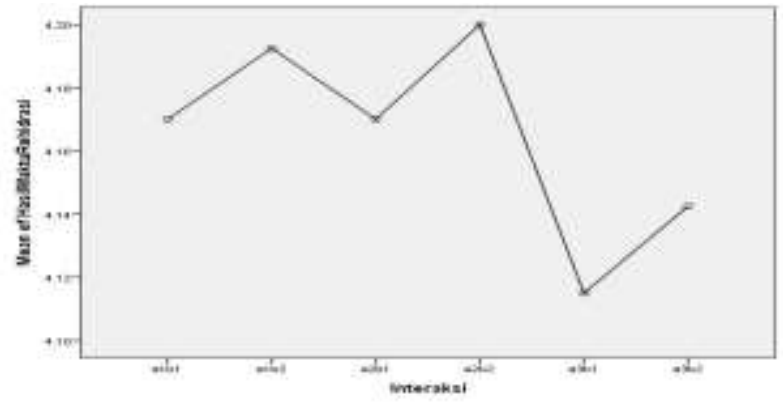

Gambar 2. Grafik Interaksi Varietas Beras Merah dan Teknik Pemasakan Terhadap Waktu Rehidrasi Nasi Merah Instan

Berdasarkan data Grafik 2 diatas rata-rata marginal varietas beras merah, teknik pemasakan dan interaksinya menunjukkan bahwa waktu rehidrasi berbeda nyata terhadap verietas beras merah dan teknik pemasakan nasi merah instan karena hal ini dipengaruhi oleh kendungan protein yang terdapat dalam ketiga varietas beras merah, dimana semakin tinggi kandungan protein maka waktu penyerapan air semakin lama sehingga mempengaruhi waktu rehidrasi nasi merah instan.

Beras yang mengandung protein tinggi memerlukan lebih banyak air dan lebih lama waktu penanakan. Hal ini berkaitan dengan struktur biji, yaitu granula pati yang diselubungi oleh lapisan protein sehingga protein menghalangi proses penyerapan air oleh granula pati yang mengakibatkan lebih lamanya waktu penanakan nasi agar gelatinisasi dapat berlangsung sempurna (Shafwati, 2012).

Waktu rehidrasi dipengaruhi oleh kadar pati yang terdapat dalam beras instan. Pati yang telah mengalami gelatinisasi mengakibatkan air yang awalnya berada diluar granula menjadi butir-butir pati dan tidak dapat bergerak dengan bebas. Pati yang dikeringkan mengakibatkan komponen air yang berada didalam matriks akan menguap meninggalkan matriks dan mengakibatkan pati bersifat porous sehingga mudah kembali menyerap air (Galung, 2017).

\section{Uji Organoleptik \\ a. Warna}

Atribut produk pangan yang dinilai pertama kali secara visual yaitu warna, yang memberi efek psikologis pada penerimaan konsumen. Warna produk yang unik akan lebih memberi kesan menarik perhatian konsumen dibandingkan warna produk lainnya. Warna harus menarik dan menyenangkan konsumen, seragam serta dapat mewakili citarasa yang ditambahkan (Nasution, 2014). Berikut ini adalah grafik interaksi varietas beras merah dan teknik pemasakan terhadap kontrol hasil organoleptik warna nasi merah instan pada Gambar 3. 


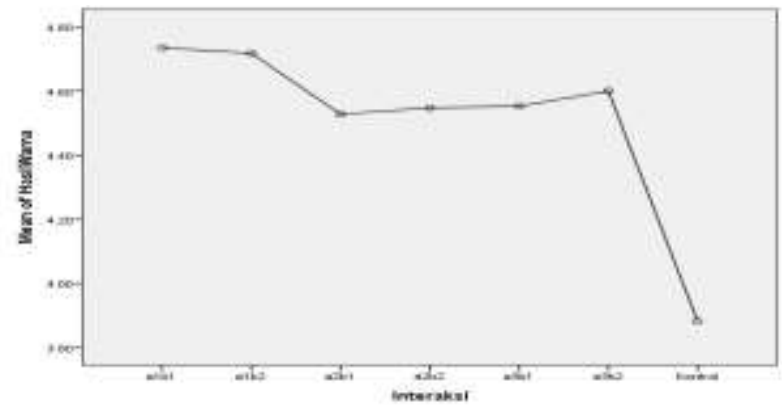

Gambar 3. Grafik Interaksi Varietas Beras Merah dan Teknik Pemasakan Terhadap Kontrol Hasil Organoleptik Warna Nasi Merah Instan

Berdasarkan hasil data Grafik 3 diatas menunjukkan bahwa secara keseluruhan memberikan perbedaan yang nyata antara varietas beras merah dan teknik pemasakan terhadap kontrol organoleptik warna nasi merah instan. Dan yang paling disukai adalah produk nasi instan $\mathrm{a}_{1} \mathrm{~b}_{1}$ (varietas Inpari 24 dengan teknik pemasakan dimasak matang) dengan hasil ratarata kesukaan panelis adalah 4.73 (agak disukai mendekati suka). Perbedaan yang nyata ini dapat disebabkan oleh perbedaan varietas yang menimbulkan keragaman warna pada berasnya, dari merah pucat sampai merah pekat. Perbedaan warna beras ini terjadi sebagai akibat adanya perbedaan kandungan antosianin (Reza, 2012).

Degradasi antosianin dimungkinkan juga terjadi selama proses penyeduhan atau penanakan. Suhu panas selama penanakan menjadi nasi menyebabkan hilangnya glikosil pada antosianin dengan hidrolisis ikatan glikosidik. Aglikon yang dihasilkan kurang stabil dan menyebabkan hilangnya warna pada antosianin (Hermawan, 2012).

\section{b. Aroma}

Aroma merupakan salah satu faktor penting bagi konsumen dalam memilih produk makanan yang disukai. Winarno (2002), menyatakan bahwa dalam kelezatan suatu makanan ditentukan oleh aroma atau bau dari makanan tersebut. Aroma dihasilkan oleh senyawa-senyawa volatil yang terdapat pada bahan pangan yang dapat digunakan sebagai indikator kelezatan suatu produk makanan. Berikut ini adalah grafik interaksi varietas beras merah dan teknik pemasakan terhadap kontrol hasil organoleptik aroma nasi merah instan pada Gambar 4.

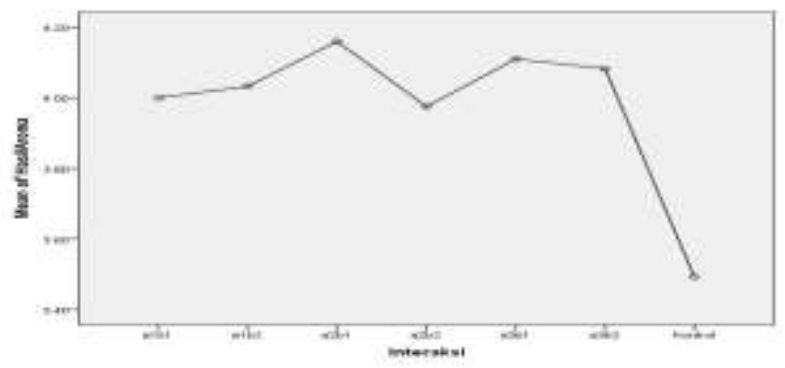

Gambar 4. Grafik Interaksi Varietas Beras Merah dan Teknik Pemasakan Terhadap Kontrol Hasil Organoleptik Aroma Nasi Merah Instan

Berdasarkan data Grafik 4 di atas menunjukkan bahwa secara keseluruhan memberikan perbedaan yang nyata antara varietas beras merah dan teknik pemasakan terhadap kontrol organoleptik aroma nasi merah instan. Dan yang paling disukai adalah produk nasi instan $a_{2} b_{1}$ (varietas Inpara 7 dengan teknik pemasakan dimasak matang) dengan hasil rata-rata kesukaan panelis adalah 4.16 (agak disukai mendekati suka), dan yang kurang disukai adalah produk $\mathrm{a}_{2} \mathrm{~b}_{2}$ dengan nilai respon kesukaan panelis 3.98 (varietas Inpara 7, dimasak setengah matang). Hal ini dikarenakan beras yang mengandung amilosa sedang mempunyai nilai aroma nasi yang lebih tinggi daripada beras yang beramilosa tinggi. Hal ini disebabkan kadar amilosa rendah memiliki konsistensi gel yang lunak, mempunyai afinitas terhadap senyawa-senyawa aroma yang lebih rendah daripada beras beramilosa tinggi (Juliano, 1994).

Menurut De Man (1997), dalam industri pangan pengujian aroma atau bau dianggap penting karena dapat memberikan hasil penilaian terhadap suatu produk terkait diterima atau tidaknya suatu produk. Timbulnya aroma ini karena zat bau tersebut bersifat volatil (mudah menguap), serta sedikit larut air dan lemak.

\section{c. Rasa}

Cita rasa dipengaruhi oleh flavour yang dapat memberikan rangsangan pada indera penerima pada saat mengecap sehingga memberi kesan yang ditinggalkan pada indera perasa setelah seseorang tersebut mengkonsumsi produk (Winarno, 2002). Berikut ini adalah grafik interaksi varietas beras merah dan teknik pemasakan terhadap kontrol hasil organoleptik rasa nasi merah instan pada Gambar 5.

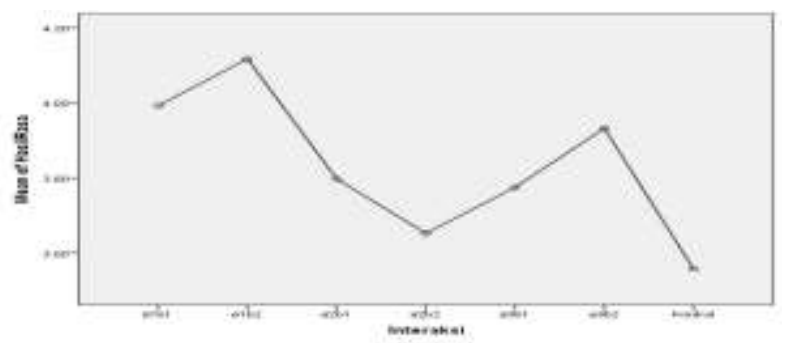

Gambar 5. Grafik Interaksi Varietas Beras Merah dan Teknik Pemasakan Terhadap Kontrol Hasil Organoleptik Rasa Nasi Merah Instan

Berdasarkan hasil data Grafik 5 diatas menunjukkan perbedaan yang nyata terhadap rasa nasi merah instan. Karena pengaruh varietas beras merah dan teknik pemasakan terhadap kontrol nasi merah intsan ini terhadap nilai rasa hedonik memberikan nilai tertinggi yaitu 4.12 dengan kriteria agak disukai mendekati suka $\mathrm{a}_{1} \mathrm{~b}_{2}$ (varietas Inpari 24 dimasak setengah matang). Hal ini disebabkan oleh mutu cita rasa oleh tingkat kepulenan, kemekaran, aroma, warna nasi, dan rasa 
nasi. Walaupun sifat genetis beras merupakan faktor utama dalam evaluasi mutu rasa, tetapi faktor pemasakan seperti perbandingan antara beras dan air serta lamanya pemasakan juga mempengaruhi mutu rasa. Mutu rasa lebih ditentukan oleh faktor subyektif yang dipengaruhi oleh lokasi, lingkungan, suku bangsa, pekerjaan dan pendidikan (Soenardjo, 1991).

Selain itu, selama proses pemasakan nasi merah dengan kedua teknik pemasakan ini maka kadar gula reduksi pada nasi merah mengalami peningkatan akibat dari proses hidrolisis pati yang memecah molekul amilum menjadi bagian yang lebih sederhana seperti dekstrin, isoaltosa, maltose dan glukosa (Purba, 2009). Sehingga meningkatkan kandungan gula reduksi pada nasi yang mengakibatkan rasa nasi merah instan cenderung semakin manis dan agak disukai panelis.

\section{d. Tekstur Mouthfeel}

Kandungan amilosa berkaitan dengan jumlah penyerapan air serta pengembangan volume nasi selama proses penanakan. Semakin tinggi kadar amilosanya, maka nasi akan semakin kurang lekat. Beras yang mengandung kadar amilosa tinggi akan menghasilkan nasi dengan tekstur pera serta kering, sebaliknya jika beras mengandung kadar amilosa rendah maka akan menghasilkan nasi yang pulen dan lunak (Shafwati, 2012). Berikut ini adalah grafik interaksi varietas beras merah dan teknik pemasakan terhadap kontrol hasil organoleptik tekstur mouthfeel nasi merah instan pada Gambar 6.

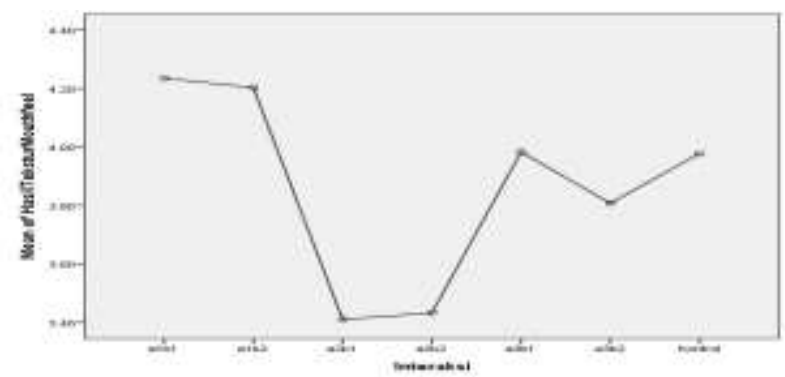

Gambar 6. Grafik Interaksi Varietas Beras Merah dan Teknik Pemasakan Terhadap Kontrol Hasil Organoleltik Tekstur (Mouthfeel) Nasi Merah Instan

Berdasarkan hasil data Grafik 6 diatas menunjukkan Perbedaan yang nyata terhadap tekstur (mouthfeel) nasi merah instan. Karena pengaruh varietas beras merah dan teknik pemasakan terhadap kontrol nasi merah intsan ini terhadap nilai tekstur hedonik memberikan nilai tertinggi yaitu 4.23 dengan kriteria agak disukai mendekati suka $\mathrm{a}_{1} \mathrm{~b}_{1}$ (varietas Inpari 24 dimasak matang). Perbedaan yang nyata ini karena beras merah dengan kadar amilosa rendah (kurang dari $19 \%)$ sehingga tekstur nasinya lebih lengket daripada beras yang mengandung amilosa lebih tinggi, sehingga menghasilkan tekstur nasi yang lebih pulen walaupun dibiarkan semalaman (Haryadi, 2013).

Apabila dibandingkan dengan teknologi pengawetan makanan secara konvensional, point utama pengeringan beku ini meliputi: suhu yang lebih rendah, retensi morfologi, sifat biokimia, viabilitas tinggi, serta tidak mempengaruhi atau merubah aroma serta salah satu hal yang berpengaruh terhadap tekstur adalah retensi struktur, luas permukaan, berat yang berkurang selama penyimpanan, serta produk yang dihasilkan dari proses pengeringan beku juga memiliki tekstur yang lebih porus (Pan dkk., 2008).

Berdasarkan data hasil penelitian tahap kedua respon kimia, fisik dan organoleptik di atas dapat disimpulkan bahwa sampel dengan perlakuan menggunakan varietas beras merah Inpari 24 dan teknik pemasakan yang dimasak setengah matang memperoleh total nilai tertinggi berdasarkan respon kimia dan organoleptik.

\section{Penelitian Tahap Ketiga}

Penelitian tahap ketiga merupakan kelanjutan dari penelitian tahap kedua yaitu sampel terpilih dengan nilai tertinggi dari penelitian tahap kedua lalu dibandingkan hasil analisis kimia dan fisiknya dengan menggunakan 2 metode pengeringan dengan menggunakan metode pengeringan beku (freeze drying) dan metode pengeringan panas (tunnel drying). Berikut ini adalah hasil analisis sampel terpilih dengan menggunakan metode pengeringan beku (freeze drying) dan metode pengeringan biasa/panas (tunnel drying) pada Tabel 2 dan 3 .

Tabel 2. Analisis Sampel Terpilih dengan Metode Pengeringan Beku (Freeze Drying) Penelitian Tahap Ketiga

\begin{tabular}{|c|c|c|c|}
\hline \multicolumn{4}{|c|}{ Pengeringan Beku (Freeze Drying) } \\
\hline $\begin{array}{c}\text { Protein } \\
(\%)\end{array}$ & $\begin{array}{c}\text { Antosianin } \\
(\mathrm{mg} / \mathrm{l})\end{array}$ & $\begin{array}{c}\text { Waktu } \\
\text { Rehidrasi } \\
(\mathrm{menit})\end{array}$ & $\begin{array}{c}\text { Serat Pangan } \\
(\text { Dietary Fiber }) \\
(\%)\end{array}$ \\
\hline 4.181 & 5.13 & 4.19 & 12.01 \\
\hline
\end{tabular}

Tabel 3. Analisis Sampel Terpilih dengan Metode Pengeringan Biasa/Panas (Tunnel Drying) Penelitian Tahap Ketiga

\begin{tabular}{|c|c|c|c|}
\hline \multicolumn{4}{|c|}{ Pengeringan Biasa (Tunnel Drying) } \\
\hline $\begin{array}{c}\text { Protein } \\
(\%)\end{array}$ & $\begin{array}{c}\text { Antosianin } \\
(\mathrm{mg} / \mathrm{l})\end{array}$ & $\begin{array}{c}\text { Waktu } \\
\text { Rehidrasi } \\
(\text { menit })\end{array}$ & $\begin{array}{c}\text { Serat Pangan } \\
(\text { Dietary Fiber }) \\
(\%)\end{array}$ \\
\hline 4.043 & 2.67 & 5.30 & $6,74 \%$ \\
\hline
\end{tabular}

Berdasarkan Tabel 2 dan 3 menunjukkan bahwa terdapat perbedaan yang nyata hasil dari kedua metode pengeringan yaitu metode pengeringan beku (freeze drying) dan metode pengeringan biasa / panas (tunnel drying), terlihat pada hasil analisis kadar antosianin, protein dan serat pangan (dietary fiber) terdapat perbedaan, untuk yang menggunakan metode pengeringan beku (freeze drying) dari mulai bahan baku hingga menjadi produk dari penelitian tahap pertama, kedua hingga tahap ketiga hasilnya cenderung stabil tidak terjadi penurunan yang signifikan, walaupun ada penurunan itu karena pada pembuatan nasi merah instan ini sebelum proses pengeringan beku dilakukan proses pemanasan terlebih dahulu, namun setelah menjadi nasi 
yang dilakukan proses pengeringan beku hingga menjadi produk nasi merah instan hasilnya cenderung stabil tidak mengalami penurunan baik secara kimia, organoleptik dan fisik waktu rehidrasi yang lebih cepat karena mempunyai tingkat porusitas yang lebih baik menggunakan metode pengeringan beku ini, bila dibandingkan dengan menggunakan metode pengeringan menggunkan udara panas (tunnel drying) yang terjadi penurunan secara signifikan.

Stabilitas antosianin tidak hanya dipengaruhi oleh suhu pemanasan pada proses pengolahan saja, tetapi juga dipengaruhi oleh faktor intrinsik dan ekstrinsik dalam produk, seperti suhu penyimpanan, $\mathrm{pH}$, struktur kimia serta konsentrasi antosianin yang terdapat pada bahan, cahaya, oksigen, enzim, protein, dan ion logam (Nanik dkk., 2013).

Selain dari proses pengolahan, protein dapat terdegradasi selama proses penyimpanan. Penurunan protein selama penyimpanan terjadi karena degradasi protein oleh mikroba yang bersifat proteolitik. Kadar protein bahan pangan yang masih berupa biji-bijian selama penyimpanan akan mengalami penurunan kadar protein karena proses respirasi (Fibriyanti, 2012).

Penurunan serat pangan (dietary fiber) sebesar $4,33 \%$ dari bahan baku awal sebelum proses pengolahan sebesar $16,34 \%$, setelah proses pengolahan menjadi $12,01 \%$, terjadi penurunan karena adanya proses pemasakan (panas) beras menjadi nasi sebelum proses pengeringan beku. Hal ini diperkuat menurut hasil penelitian Pangastuti dkk (2013), Hasil serat pangan total sebelum direbus $43,97 \pm 0,38 \%$ dan setelah direbus menjadi $40,17 \pm 0,52 \%$. Perebusan selama 5 menit pada suhu $90^{\circ} \mathrm{C}$ menyebabkan penurunan kadar serat pangan total. Kadar serat pangan total diperoleh dari hasil penjumlahan serat pangan larut dan tak larut.

\section{Kesimpulan}

Berdasarkan hasil penelitian, dapat diambil kesimpulan pada hasil penelitian tahap pertama diperoleh data bahwa varietas Inpari 24 berdasarkan hasil analisis kimia memperoleh nilai tertinggi dari respon kadar antosianin, kadar protein, dan kadar serat pangan (dietary fiber). Selanjutnya berdasarkan hasil penelitian tahap kedua pengaruh varietas beras merah dan teknik pemasakan terhadap stabilitas nutrisi nasi merah instan dengan menggunakan metode pengeringan beku (freeze drying) dengan olah data statistik SPSS 21.0 Two Way Anova Post Hoc Dunnet's diperoleh hasil sampel terpilih $\mathrm{a}_{1} \mathrm{~b}_{2}$ unggul berdasarkan respon kimia kadar antosianin $(5,13 \mathrm{mg} / \mathrm{l})$ dan respon organoleptik berdasarkan atribut warna $(4,72)$, rasa $(4,12)$, dan tekstur $(4,20)$. Lalu hasil penelitian tahap ketiga analisis sampel terpilih dan perbandingan dengan dua metode pengeringan yaitu metode pengeringan beku (freeze drying) dan metode pengeringan panas (tunnel drying) terhadap stabilitas nutrisi nasi merah instan secara kimia dan fisik yaitu sampel dengan menggunakan metode pengeringan beku (freeze drying) memiliki nilai terbaik.

\section{Daftar Pustaka}

1. Afza, Higa. 2016. Jurnal Litbang Pertanian. Vol 35. No. 3 September 2016: 143-145.

2. Anggraeni, V.J. Ramdanawati, L. Ayuantika, W. 2018. Penetapan Kadar Antosianin Total Beras Merah (Oryza nivara). J. Kartika Kimia. Nov 2018, $1,(1), 11-16$.

3. De Man, J.M. 1997. Kimia Makanan. (Terjemahan dari Principles of Food Chemistry, diterjemahkan oleh Padmawinata, Prof. Dr. Kosasih). Institute Pertanian Bogor. Bogor.

4. Eldridge, J.A., Repko, D., dan Mumper, R.J. 2014. Retention of Polyphenols Species in Spray-Dried Blackberry Extract using Manitol as a Thermoprotectant. Journal of Medicinal Food. 10. 1064-1069. Doi: 10.1089/jmf.2013.0177.

5. Fibriyanti, Y.B. 2012. Kajian Kualitas Kimia dan Biologi Beras Merah (Oryza nivara) dalam beberapa Pewadahan Selama Penyimpanan. Universitas Sebelas Maret. Surakarta.

6. Galung FS. 2017. Karakterisasi dan Pengaruh Berbagai Perlakuan terhadap Produksi Tepung Beras Merah (Oryza nivara) Instan. Fakultas Pertanian. Universitas Cokroaminoto Palopo.

7. Harini S. 2013. Perbedaan Nilai Indeks Glikemik Beras Hitam (Oryza sativa L. Indica), Beras Merah (Oryza nivara), dan Beras Putih (Oryza sativa). Program Studi Pendidikan Dokter FKUB.

8. Hariyadi, P. 2013. Freeze Drying Technology: For better quality \& flavor of dried products. Foodreview Indonesia. 8 (2):52-57.

9. Hermawan, R. 2012. Effect of Temperature, $p H$ on Total Concentration and Color Stability of Anthocyanins Compound Extract Roselle Calyx (Hibicus sabdariffa L.). ALCHEMY, Vol. 2 N0. 1. Jurnal.

10. Indrasari, S.D dan Adnyana. 2007. Preferensi Konsumen Terhadap Beras Merah Sebagai Sumber Pangan Fungsional. Dalam : Iptek Tanaman Pangan 25(3): 194-199.

11. Juliano, B.O. 1994. A Simplified Assay for Milded Rice Amylase. Cereal Science Today 16 : 334-360.

12. Katsube N, Iwashita K, Tsushida T, Yamaki K, Kobori M. 2003. Introduction of Apoptosis in Cancer Cells by Bilberry (Vaccinium myrtillus) and the Anthocyanins. Journal of Agricultural and Food Chemistry. Jan 1;51(1):68-75.

13. Luna P, Herawati H, Widowati S, dan Priyanto AB. 2015. Pengaruh Kandungan Amilosa Terhadap Karakteristik Fisik dan Organoleptik Nasi Instan. Balai Besar Penelitian dan Pengembangan Pascapanen Pertanian. Bogor.

14. Mardiah, Z. 2017. Identifikasi Kandungan Fenolik Total, Antosianin Total dan Asam Fitat Pada Beberapa Varietas Unggul Baru Beras Berwarna (Identification of Total Phenolic Content, Total Anthocyanins and Phytic Acid on Some New 
Pigmented Rice Varieties). Balai Besar Penelitian Tanaman Padi (BB Padi).

15. Monika P, Saputrajaya W, Liguori C, Widyawati PS, Suteja AM, dan Suseno TIP. 2013. Aktivitas Antioksidan Beras Organik Verietas Lokal (Putih Varietas Cianjur, Merah Varietas Saodah, Hitam Varietas Jawa). Seminar Nasional: Menggagas Kebangkitan Komoditas Unggulan Lokal Pertanian dan Kelautan. Fakultas Pertanian Trunojoyo. Madura.

16. Nanik, S., Karyantina, M., Mustofa, A., Cahyanto, M.N., Raharjo, S., dan Rahayu, E.S. 2013. Stabilitas Ekstrak Antosianin Beras Ketan (Oryza sativa var. glutinosa) Hitam Selama Proses Pemanasan dan Penyimpanan. Jurnal Agritech Vol 33 No. 4.

17. Nasution, A.Z. 2014. Hukum Perlindungan Konsumen di Indonesia. Bandung. PT Citra Adiya Bakti.

18. Pan Z., Shih C., McHugh T.H., dan Hirschberg E. 2008. Study of Banana Dehydration Using Sequential Infrared Radiation Heating and FreezeDrying. LWT-Food Sci. Technol 41, 1944-1951.

19. Pangastuti, H.A., D.R. Affandi, dan D. Ishartani. 2013. Karakterisasi sifat fisik dan kimia tepung kacang merah (Phaseolus vulgaris L.) dengan beberapa perlakuan pendahuluan. J. Teknosains Pangan. 2(1):20-29.

20. Purba, R.P. 2009. Produksi Etanol dengan Variasi Inokulum dan Kadar Pati Jagung pada Kultur Sekali Unduh. Yogyakarta : UAJY.

21. Rahmat, R. 2010. Stabilisasi Mutu Beras Pecah Kulit Melalui Penerapan Teknologi Penyimpanan Hermetik.http://www.majalahpangan.com/2010/04/s tabilisasi-mutu-beras-pecah-kulit-melalui penerapanteknologi-penyimpanan-hermetik/

22. Rewthong, O., S. Soponronnarit, C. Taechapairoj, P. Tungtrakul, dan S. Prachayawarakorn. 2011. Effects of cooking, drying and pretreatment methods on texture and starch digestibility of instant rice. Journal of Food Eng. 103:258-264.

23. Reza, M. 2012. Evaluasi Kandungan Antosianin, Amylosa dan Serat beberapa Kultivar padi beras Merah (Oryza sativa. L). Universitas Andalas. Padang.

24. Shafwati, R Afni. 2012. Pengaruh Lama Pengukusan dan Cara Penanakan Beras Pratanak Terhadap Mutu Nasi Pratanak. Skripsi Fakultas Teknologi Pertanian-Institut Pertanian Bogor.

25. Soenarjo, Edi. 1991. Padi Buku 3. Pusat Penelitian dan Pengembangan Tanaman Pangan. Bogor.

26. Syamaladevi, RM., Shyam S. Sablani, Juming, T., Joseph, P., dan Barry G. Swanson. 2011. Stability of Anthocyanins in Frozen and Freeze-Dried Raspberries during Long-Term Storage: In Relation to Glass Transition. Journal of Food Science _ Vol. 76, Nr. 6. Institute of Food Technologists.

27. Wang XS, Mollie ON, William T, Joanne S. 2013. White and Brown Rice are Equally Satiating and
More Satiating than Glucose Beverage. Journal Obesisty Weight Loss Therapy. 3(202); 2-5.

28. Winarno, F.G. 2002. Kimia Pangan dan Gizi. Gramedia Pustaka Utama. Jakarta.

29. Yodmanee, S., Karrila, T.T. dan Pakdeechanuan, P. 2011. Physical, Chemical and Antioxidant Properties of Pigmented Rice Grown in Southern Thailand. International Food Research Journal 18: 901-906. 